\title{
A Sociological Reconstruction of Memory, The case of Iranian Exile
}

\author{
Nader Vahabi \\ School of Advanced Studies in Social Sciences (CADIS), Paris, France \\ University of Toulouse (Rural Dynamics), Toulouse, France
}

\begin{abstract}
It has been 36 years since exiled Iranians who were eliminated from society in Iran settled in Europe and in the world and found safety in exile. How can we assess their memory? How does memory construct and modify over the course of time? How can life trajectories and social processes affect and transform their memory? The response to these questions inevitably leads us towards an analysis of the social dynamics of memory. What we have to contend with is not just a simple recording of memories pulled from oral histories. Our research is mainly centered on a sociological analysis of memory. This paper locates itself at a crossroads between two methodologies: The first has been gleaned from E. Goffman's concept of "moral career” and the second is heavily inspired by M. Halbwach's sociology where: New social frameworks shatter memory. For this reason, the supposed "collective" and "homogenous" memory, forged during the Iranian revolution of 1979 and shown to be ultimately subjective, cannot be conserved intact in exile. In point of fact, memory breaks down progressively when the social frameworks for individual resocialization exploit different places of exile. Memory then transforms itself with due respect to the new social environments, and this is a specific feature of the life trajectories of those exiled. This paper is a result of our research on the subjectivity of 200 Iranian political migrants carried out since our thesis in 2003 in seven countries, Turkey (Istanbul), France (Paris, Toulouse, Montpellier), Germany (Cologne), England (London), Hungry (Budapest), Austria (Vienna).
\end{abstract}

Keywords: collective memory, Iranian exile, moral career, the social dynamics of memory

\section{Presentation}

The interviews in our enquiry represent four transversal waves of those experiencing exile in the history of contemporary Iran $^{1}$. Exiles ask for political asylum as soon as they arrive in the host country. Demands for asylum are systematically examined with regard to International Law which has not, as far as we know, evolved since the Second World War. According to the Geneva Convention (1951) and the New York Protocol (1967), a refugee is: "A person who owing to a well-founded fear of being persecuted for reasons of race, religion, nationality, membership of a particular social group or political opinion, is outside the country of his

Nader Vahabi, Ph.D. in Social Politics, associate researcher in sociology School of Advanced Studies in Social Sciences (CADIS) in Paris and University of ToulouseI1 (Rural Dynamics).

Correspondence concerning this article should be addressed to CADIS, UMR 8039, CNRS-EHESS, 190-198 avenue de France 75244 Paris Cedex 13.

1 This paper is a result of our research on the subjectivity of 200 Iranian political migrants carried out since our thesis in 2003 in seven countries, Turkey (Istanbul), France (Paris, Toulouse, Montpellier), Germany (Cologne), England (London), Hungry (Budapest), Austria (Vienna). 
nationality and is unable or, owing to such fear, is unwilling to avail himself of the protection of that country; or who, not having a nationality and being outside the country of his former habitual residence as a result of such events, is unable or, owing to such fear, is unwilling to return to it" ${ }^{2}$.

The first wave began in 1979 many months before the revolution ${ }^{3}$. The peak of this wave is situated in 1988 with more than 47,000 asylum seekers ${ }^{4}$. It was a period where the Iranian population in the world grew due to the revolution and its fall into repression ${ }^{5}$ as well as the war between Iran and Iraq ${ }^{6}$.

Iranians arriving abroad during the great wave of refugees in the middle of the 1980's represent ${ }^{7}$ a range of very heterogeneous political tendencies which take in the traditional right, the royalist tendency opposed to the revolution, the technocrats having undergone purges just after the revolution (accused of being in league with the imperial regime), the revolutionary forces (the radical left, the reformists and the Moudjahedines of the people, etc.); All had actively participated in the revolution which turned against them and eliminated them from the social body ${ }^{8}$.

The second period, which began in 1988, was marked by three important events: the end of the war against Iraq in 1988, the death of Khomeini in $1989^{9}$ and the democratization of easily accessible passports to a broader public. On a political level, the death of Khomeini as a charismatic figure of the revolution prepared the context for the 1990-1998 decade, which with its strong social connotations, was marked by the regime's opening up to reform boosted by Presidents Rafsanjani and Khatami ${ }^{10}$. The causes for immigration diversified becoming social, intellectual and cultural ${ }^{11}$.

The third wave ${ }^{12}$ developed between 1999 and 2009, a period when there was a migratory avalanche towards foreign parts which rose to a peak of 35,000 applications in $2000^{13}$. During the decade 2000, the reasons for migrating were numerous with, principally, a rise in the number of economic migrants who still conserved their political "background". Four factors can explain the growing number of migrants: the wave that came about following the riots at Teheran University in 1999 marked the end of the period of reform by Khatami who to a certain extent, wanted to incarnate the new horizons of Iranian social classes ${ }^{14}$. The second factor was an external one, as we have showed in a previous work, the political situation in Bosnia allowed

2 http://www.unhcr.fr/pages/4aae621e11f.html, consulted 20 .06. 2013.

3 For the revolutionnary period, see, Yan Richard, L'Iran, Naissance d'une république islamique, Paris, Editions de la Martinière, 2006, p. 313-336.

4 All the figures have been taken from the annual report of UNCHR. file://C:/Users/ZINAT/Documents/Downloads/UNHCR+-+Asylum+trends+2013.pdf, consulted 13.01.2011

Iranian Refugees’ Alliance, New York, http://www.irainc.org/iranref/statistics.php, consulted 13.01.2011.

Cf also, Nader Vahabi, Atlas de la diaspora iranienne, Paris, Karthala, 2012, p. 47.

${ }^{5}$ For the nature of the regime in this period, see H. Arendt, Les Origines du totalitarisme. Le système totalitaire, Paris, Le Seuil, 1972, p. 189-267.

${ }^{6}$ For the period of the revolution and the Iran-Iraq War, cf. KHOSROKHAVAR F., Utopie sacrifiée, Paris, Presses de la Fondation Nationale des Sciences politiques, p 81-93.

7 For the refugees of this period, see, Maboud Ansari, The making of the Iranien Community in America, Paradis Press, 1992, p. $10-40$.

${ }^{8}$ To understand better the context of departure for this wave, cf. Nader Vahabi, Sociologie d'une mémoire déchirée, Le cas des exilés iraniens, Paris, Harmattan, p. 65-100.

9 For Khomeini's role in the revolutionary imagination, cf Farhad Khosrokhavar Utopie sacrifièé, op, cit, p 223-245.

${ }^{10}$ Fariba Adelkhah, Etre moderne en Iran, Paris, Karthala, coll.«Recherches internationales», 1998, p. 10-11.

11 Nader Vahabi, La migration iranienne en Belgique, une diaspora par défaut, Paris, l’Harmattan, 2011, p. 74-77.

${ }^{12}$ To understand the meaning of the wave, cf. E.K. KUNZ, Les réfugiés en exode: les modèles dynamiques et les formes de déplacement, International Migration, vol 7,2, p.155-160.

${ }^{13}$ For these years, see, http://www.unhcr.org/statistics/populationdatabase, consulted 06. 05. 2012.

${ }^{14}$ For the riots at Teheran University cf. Mohammad Reza Djalili, Iran: l’illusion réformiste, Paris, Presses de Sciences Po, coll. «La bibliothèque du citoyen», 2001, p.112. 
Iranians to go directly and without a visa to countries close to the European Union; this has an impact on the third factor, a geographical one, since Belgium had become the anti-chamber to enter the easily accessible England where immigrants found work and promotion ${ }^{15}$.

This population of migrants is relatively young, between 22 and 35 years, for most of the individuals who were interviewed, and who were motivated for economic reasons ${ }^{16}$.

The fourth wave began in 2009 and has pursued to the present day. Since the presidential elections of June $2009^{17}$, a new wave of exodus towards Western countries (Europe, the United States, Canada, etc.) has risen. This surge, 18,000 people in $2010^{18}$, is largely due to the anti-establishment movement of June 2009 which has been severely reprimanded by the regime from July $2009^{19}$. It is too early to decrypt an exhaustive analysis of the socio-economic profile of this fourth wave of migration but the last figure in 2013 (24,000 individuals) ${ }^{20}$ shows that it hasn't stopped. It is interesting to note that the individuals concerned, often in favour of the regime before the election, turned against it and made the decision to leave.

\section{Socio-economic Characteristics of the Interviews}

On a professional level, 100 persons out of 200 (50\%) have stable employment (this means that they don't want to change jobs for the rest of their lives in exile) and are not considering returning to Iran. What is interesting in this profile is that these individuals have in most cases an independent occupation and they explain that due to their political past, they can no longer bear to receive orders from hierarchy. There are 40 persons out of 200 (20\%) without employment (25 unemployed and 15 retired). The high rate of unemployment in relation to the destination country underlines their difficulties entering employment in the host country. There are 60 persons out of 200 (30 \%) employing in casual jobs but prefer to keep them rather than look for a stable job, because they consider that there is no work that values their level, in as far as they suffer from a declining social status ${ }^{21}$.

Is there a relationship between entry into the professional world in the life of the host country and the memory that these exiles maintain with their past? The most likely hypothesis enhanced through research would seem to indicate that more the refugees implemented themselves in active life in the host country, more they would change their lifestyle with regard to the country of origin and less would be preoccupied with their souvenirs. The social mechanisms ${ }^{22}$ of the process of resocialization in the host countries and the intensity of integration would therefore constitute, paradoxically, a negative element in the construction of memory.

\section{Three Categories of Attitude Faced With Memory}

Through 200 interviews with Iranian migrants, I have tried to record the lived experience of these people in relation to their new subjectivities ${ }^{23}$ in the host countries.

\footnotetext{
15 Nader Vahabi, La migration iranienne en Belgique, une diaspora par défaut, p. 80-83.

16 Nader Vahabi, La quatrième socialisation de la diaspora iranienne, Les Iraniens en Belgique, Paris, Orizons, 2013, p. $296-300$.

${ }^{17}$ For the stakes of this election, see Iran: a civil revolution? Fondation pour l'innovation politique, October 2009, p.6.

$18 \mathrm{http}: / /$ www.unhcr.org/pages/4a013eb06.html, consulté le 20 juin 2014

19 To understand the stakes of the movement, see F. Khosrokhavar and M. Ladier-Fouladi, The 2009 Presidential election in Iran: fair or foul? Consulted, 30.06 .2012. http://cadmus.eui.eu/bitstream/handle/1814/22564/RSCAS_2012_29.pdf?sequence=1.

${ }^{20}$ UNCHR report 2013, http://www.unhcr.org/pages/4a013eb06.html, consulted 20.06.2014.

${ }^{21}$ To understand the characteristics of exiles in a better way, cf. Nader Vahabi, La migration iranienne en Belgique, p. 24-32.

${ }^{22}$ For a better understanding of these mechanisms, cf. Luwing and Thomas Luckman, The Social Construction of Reality, A Treatise in the Sociology of Knowledge, London, the Penguin Press, 1967, p. 30-60.

${ }^{23}$ To understand the relation between subjectivity and reality, cf. Luwing and Thomas Luckman, The Social Construction of Reality,op.cit. p. 10-30.
} 
This research has emphasized the importance of the subjective relation of these "intense moments" in the constitution of their memory by discovering several forms of memory that we can classify in three categories ${ }^{24}$.

\section{The Apolitical Exile}

Some interviews have underlined a type of political exile no longer interested in Iran's political ${ }^{25}$ life and who criticizes his own past behaviour with regard to the Islamic Republic. Moreover, these exiles are not at all concerned with the commemoration of past events, even seeking to ignore or forget them. While at the time of departure, they believed in the armed struggle, they have now totally lost interest and anecdotes evoking this past leave them indifferent ${ }^{26}$. They show no interest for matters around memory, encountering a sense of remorse even waste, faced with the loss of their youth which they hope will not happen again for others. They don't wish to be implicated anymore in political issues and more or less envisage openly returning to Iran, although they rejected this eventuality when they settled in the host country. They don't have any scruples handing back their refugee $\operatorname{card}^{27}$. In fact, either they leave to settle definitely in Iran either they go back for holidays but in any case retrieve from political life in the Islamic Republic.

The trajectory ${ }^{28}$ of these individuals shows that they are looking for stable and solid employment and no longer believe in ongoing revolutionary activities, contrary to the emblematic figures of the 1960s and 1970s. Consequently, since then, the political voice that these exiles had at the time of departure has completely changed. They no longer consider themselves as political refugees and express their disapproval with regard to the revolution, whatever their angle of approach is.

\section{The Second Category: The Committed Political Exile}

By contrast, there is a second profile with different characteristics. These are individuals who consider pertinent political activities undertaken from exile against the present Iranian regime ${ }^{29}$. The struggle represents for them a social ideal even if some take a critical look on the past. They always remain hostile to the present regime and don't express any criticism about their own behaviour with regard to the regime ${ }^{30}$. They often evoke the ironical equation one hundred against zero: all problems come from the regime but we are pure.

Unlike members of the previous category, they are especially sensitive to the commemoration of past events. These are individuals who give importance to the traces of experience, who try not to forget the past and who insist on keeping political asylum status. They try to keep their political identity and hope for change in Iran, but are sensitive to the transmission of their memory to their children and are greatly interested in the facts of memory, even if they are not very highly considered in their host country ${ }^{31}$.

As long as the regime in place persists, they are not planning an early return to Iran and place high value on the political refugee card considering it as "sacred". It is out of the question for them to send back their card

\footnotetext{
${ }^{24}$ For the method of analysis in sociology, cf. Pierre Bourdieu, La misère du monde, Paris, éditions du Seuil, 1993, p.10-63.

${ }^{25}$ To understand the meaning of politics in sociology, cf. Max Weber, Le savant et le politique, Paris, Union générale d'éditions, 1963, p.137-138.

${ }^{26}$ As an example, see interview with M. K, Nader Vahabi, Récits de vie des exilés iraniens, De la rupture biographique à la nouvelle identité, Paris, Elzavir, 2009, 184-193.p

27 See the life story of an exile who returned to Iran E. S, Nader Vahabi, Récits de vie des exilés iraniens, op.cit. p. 297-312.

${ }^{28}$ For the meaning of trajectory in sociology,, cf. Anselm STRAUSS, La trame de la négociation : sociologie qualitative et interactionnisme, textes réunis par Isabelle BAZANGER, Paris, L'Harmattan, 1992, p.143.

${ }^{29}$ To understand political activities in exiles better, cf. Shain, Yossi, Who is a political exile? , Revue Internationale Migration, vol. 26, No. 4, 1988, p.380-403

${ }^{30}$ For this profile of exiles, cf. Nader Vahabi, La quatrième socialisation de la diaspora iranienne, op.cit, p. 129-183.

31 We can see this profile of exile with Anvar Mirssattari, cf. Nader Vahabi, La quatrième socialisation de la diaspora iranienne, p. 235-244.
} 
and they even go as far as treating exiles of the first category, those who have returned their card, as "opportunists" and "traitors". They refute this attitude of repenting which reflects the wish of an early return to Iran because they think that this return confers true legitimacy to the regime, implying that the situation is acceptable in Iran and that there is no reason to remain in exile.

The trajectories of these individuals show that they aren't looking for stable and permanent employment and that some of them don't even take the nationality of the host country, even if it is their right.

The profile of this sort of exile is likely to be found in the final sentence of E. Hobsbawn's ${ }^{32}$ Franc-Tireur (maverick): "We need to continue to fight and condemn social injustice. The world will not heal alone". This conviction constitutes for these committed political exiles a "moral compass" which generates fidelity and constancy in their lives and consequently results in the need to overthrow a regime which doesn't belong to this century.

\section{The Third Category: The Exile With Variable Geometry}

Alongside these two categories of exiles, there is a third one which corresponds to what we can call "exiles with variable geometry", or, as they put it, exiles who are rather "pragmatic", "realistic" or "independent" "33. The distinctive character of this group is the resentment they have towards the direction of "the apparatus", towards the "leaders" and towards political activities with a Marxist model that comes from a classical democratic-centralist tendency inspired from Lenin. The defenders of this category all refuse projects or ideas imposed on them from outside ${ }^{34}$.

Generally, they seek to integrate actively in the host countries by mastering the language and are in search of stable employment. Once they have overcome the problems of language, employment, housing, etc. they occasionally do politics. Some of them are interested in memory, but others remain totally indifferent to this subject.

This category would in fact like to show that the militant configuration, inherited principally from trade union struggles, organisation struggles and the associations of the civil society in the years 1960-1970, which showed itself capable of ensuring forms of social regulation opposed to the State, has proved to be less and less effective.

This means that voluntary intervention coming from abroad against the Islamic Republic would at the present time, be on the decrease, in favor of a shift proclaimed towards the private sphere ${ }^{35}$. For these exiles, activism as it has been exercised since the Iranian revolution is only a lapsed method. New forms of social participation, currently in progress in the host ${ }^{36}$ country, seem to be better suited to the evolution of relations between individuals and politics.

Furthermore, the arrival of internet and the emergence of Iranian websites abroad, allow relations without any hierarchy to be established between exiles, so much so that, these persons are more and more suspicious of vertical structures of combat apparatus, privileging horizontal models of relations, communications and doing politics mainly in small groups of two to ten members.

\footnotetext{
32 Jean-Louis Robert, presentation of E. Hobsbawm, Franc-Tireur. Autobiography Ramsay, Paris, 2005, 600 p., in the Diplomatic World, February 2006, p21

${ }^{33}$ We can see certain of these expressions in the interview with D. I cf, Nader Vahabi, Récits de vie des exilés iraniens, op.cit. p. 148-166.

${ }^{34}$ We can see in an interview with B. A, Nader Vahabi, Récits de vie des exilés iraniens, op.cit. p. 88-104.

35 This problematic is exposed by Ion Jacques, La fin des militants, Paris, Published by Les Editions de l'Atelier, Editions ouvrières, 1997, pp. 5-20.

${ }^{36}$ For a deeper study of this problematic Cf. Annie Collovald, Hélène Lechien, Sabine Rosier and Laurent Willemez, L'humanitaire ou le management des dévouements, Enquête sur un militantisme de "solidarité internationale" en faveur du Tiers-Monde, Rennes, Presses Universitaires de Rennes, 2002, pp.180-200.
} 
Not as distrustful as exiles from the first category, less obsessed by politics than those of the second category, these exiles find themselves between the two. For example, they don't return their political refugee card but some go to Iran in hiding, although it is forbidden by their political refugee status and frowned upon by other exiles. Some occasionally participate in political activities of the second category. We can find this profile of exile in Jacques Ion's book, “La fin des militants”. (The end of activists) ${ }^{37}$

The most remarkable thing about this category is that some of its members have a use of memory which is of a specific nature: They hardly speak about their experience in Iran, but have a tendency to evoke in detail the times when they were activists, because they consider that certain organizational practices were not fair when they belonged to those organizations ${ }^{38}$.

This classification in three categories, resulting from our research, has allowed me to analyse more precisely the evolution of their memories, but it has to be understood as a heuristic approach and not as a rigid division, especially since some of my counterparts might have changed categories during their exile. A direct consequence of this classification has led me towards a new course of reflection problematized in my book: Sociology of torn memory, The case of Iranian exiles, Harmattan, 2008.

\section{Initial problematic}

The categorization explained previously has therefore brought to light an unprecedented questioning: How does a political refugee manage to lose interest in a political system that is still in place, meaning the Islamic Republic, although he has been an actor implicated in the revolution and has vigorously fought against the regime within a leftist organization, sometimes during ten years or even twenty? After such a change, how has the memory of these persons evolved?

Understanding social mechanisms which have created these three groups in relation to their unique characteristics of memory has proved itself to be a question of the utmost importance, going further than the framework of the original research. What explains the differences concerning memory between the three groups? What are their characteristics?

The initial essential problematic of our research therefore resides in the question:

How does the memory of Iranian political refugees build and change over time?

Such questioning implies that it is necessary to study what are the experiences or hardships that provoke notable transformations in the memory of exiles. By adopting E. Goffman's ${ }^{39}$ approach to moral career, it is also possible to formulate this question in the following way:

What sort of personal journey can help evolve profound change in the representations the exiles have of themselves? What sort of experience, intellectual mechanism, or personal interest, leads the exile to "repress" (first category), to "maintain” (second category) or to "relocate” (third category) a series of souvenirs?

To answer these questions leads inevitably towards the social dynamic of memory, and, indeed, our initial problematic has "slid" from a simple recording of memories derived from oral history towards a social analysis of souvenir. This research will as a result pay attention to exploring the social dynamic dimension in the reconstruction of Iranian political exiles' memory ${ }^{40}$.

\footnotetext{
37 Ion Jacques, La fin des militants, op. cit. pp. 5-20.

${ }^{38}$ We can see in an interview, B. A, Nader Vahabi, Récits de vie des exilés iraniens, op.cit. p. 69-88.

39 Evring Goffman, Asiles, Etudes sur la condition sociale des malades mentaux, Paris, Les Editions de minuit, 1968, p.179-225.

40 On a comparative level I was greatly inspired by the research of Marie Claire Lavabre, Le fil rouge, Sociologie de la mémoire communiste, Paris, PFNS, 1994, p. 10-50.
} 
In my initial approach using oral history as support, I tried, like in M. Pollak's work $^{41}$, to record the memories of the political exiles in the most neutral way possible. But, because the processes of resocialization ${ }^{42}$ of emigrants in the host country affects the reconstruction of their memory, I have been obliged to orient myself towards a sociological analysis of souvenir and its mechanisms ${ }^{43}$.

Therefore, participant observation sessions with associations ${ }^{44}$ and actors in exile and readings of diverse publications have strengthened the sources around departure, and as a result, in this way the present sociological research of memory has been based on diversified material. Centered on the understanding of how, the research aims to bridge, certainly in a very fragmentary way, the gap which in the fields of study on "memory”, sometimes separates theoretical considerations from real empirical basis.

\section{The Conceptual Framework For the Research}

How does the multiplicity of experienced social frameworks be combined with the negotiation of memories? How does individual memory rebuild its past in relation to new social frameworks?

\section{For This Advancement, We Are Interested by Two Authors}

\section{Goffman's Concept of "Moral Career"}

According to this author, the term "career" is generally reserved for the process of seeking employment by individuals to establish their future career. But it is also employed in a broader sense, to qualify the social context in which every individual's life is conducted ${ }^{45}$.

For Goffman, the interest in the concept of career resides in its ambiguity. On the one hand, he applies it to different intimate meanings that each person secretly nurtures preciously such as self-esteem or one's own sense of identity; On the other, he refers to the official situation of the individual, his civil relationships, his lifestyle and hence he falls within the framework of social relations. The concept of career therefore authorizes a movement going back and forth from private to public, from an individual to his social environment ${ }^{46}$.

In our research, we use it as a transversal concept, by expressing a preference for the moral aspects of career linked to the cycle of changes that intervenes in personality on account of this career and linked also to the changes in the representations of the system by which the individual becomes self-aware and apprehensive of others.

In our study, these changes intervene in an exile's career according to five main phases ${ }^{47}$ :

The pre-exile phase,

Individuals' displacement phase

No-man's land phase

The final settling in the host country's phase

The return phase

\footnotetext{
${ }^{41}$ Pollak Michael, L'expérience concentrationnaire. Essai sur le maintien de l'identité sociale, Paris, Métailié, 2000, p. 11-22. Cf. also Pollak Michael, Une identité blessée, Etudes de sociologie et d'histoire, Métailié, 1993, p. 15-39.

${ }_{42}$ To understand the meaning of resocialisation, cf. Claude Dubar, La socialisation, Armand Colin, Paris, (4 ed.), 2010, p. 9-15.

${ }^{43}$ For a deeper study, cf. Nader Vahabi, Sociologie d'une mémoire déchirée, Le cas des exilés iraniens, p. 13-57.

${ }_{44}$ Pour la méthode de travail dans une enquête sociologique et observation participante, cf. Florence Weber, Le travail à côté, Paris, INRA, Hautes Etudes, 1989, p. 9-21.

${ }^{45}$ Erving Goffman, Asiles,op,cit.,P.179

${ }^{46}$ Erving Goffman, Asiles, op, cit.P.179-180.

47 At the beginning of our research we only thought of four phases but since 1995, returning to Iran has become something banal and necessary for a great number of Iranians. Interview with M. k, cf, Nader Vahabi, Récits de vie des exilés iraniens, p. 184-193.
} 
The reciprocity between these stages and the evolution of the exiles' representations during each phase can be best understood in accordance with the notion of "moral career", because it is better adapted to our precise problematic at the beginning of our study. Our initial problematic, in fact, was to simply record the memory of the exiles, but the categorization of three types of memory addressed at the beginning of the introduction some repress their memory, some have concerns about it and others relocate it—has pushed us towards a problematic of trajectory and towards a social analysis of souvenir.

\section{Maurice Halbwacks, The Social Frameworks of Memory}

M. Halbwacks has shown in fact that, from a sociological point of view, the past is not stored, contrary to what we commonly believe, it is in fact reconstructed from the present ${ }^{48}$.

In the case of Iranian exiles, this construction is very complex because of their conflictual trajectory and the different affiliations with different social frameworks. In other words, if we refer to Halbwach's problematic on memory we have a particular sociological profile which does not come either from the family, or a group, or a class conceptualized at the beginning of the twentieth century. But the exile's profile from a sociological point of view can be defined here by an administrative category, numerically quite weak quite disseminated and strongly affected by declassification and reclassification in resocialization in the countries of our enquiry ${ }^{49}$.

We have indeed individuals for whom memory is defined as being the interference of diverse collective memory through different sequences of their trajectories. The confrontation between the subjectivity and the sociality of exiles thus constitutes the permanent thematic, and this means that we need to study in parallel the experiences and hardships which have provoked and provoke significant changes in exiles' memory.

This step is particularly interesting in as far as it perfectly falls within the crux of our research problematic: to observe men and women, who try to live, although they are having to cope with heavy contradictions, and are settled in a new situation, beginning life from scratch ${ }^{50}$.

This new fresh start is in direct relation with the exile's way of life and varies according to the energy that he gives to the struggles against the regime, in accordance with the definition that an individual gives to his exile.

Consequently, we are going to touch the main lines of research which have become apparent during our interviews ${ }^{51}$.

1. The exile is no longer attracted by his country of origin but is by his host country.

2. The exile regrets his home country, but is not interested in his host one.

3. The exile is attracted by his home country and also by his host country.

These three elementary problematics form the basis of what defines the capacity of exiles to resocialize in the host countries and is clearly in line with interviews exiles carry out concerning their memory. We are here in fact at the heart of Halbwach's problematic concerning memory in which new social frameworks make memory explode; we will go deeper into this in the following section.

\footnotetext{
48 Maurice Halbwachs, Les cadres sociaux de la mémoire, Paris, Albin Michel, 1994, pp. 83-114.

${ }^{49}$ For the demographic study, cf. Nader VAHABI, Atlas de la diaspora iranienne, Paris, Karthlal, p. 206.

${ }^{50}$ For beginning life from scratch, cf. Nader Vahabi, La quatrième socialisation de la diaspora iranienne, Les Iraniens en Belgique, op.cit. p. 36-50.

${ }^{51}$ For a deeper study, cf. Nader Vahabi, Récits de vie des exilés iraniens, p.51-64.
} 


\section{Memory in Sociology}

Three important historical moments in the history of the contemporary world in the twentieth century have pushed individuals, and in particular researchers, towards the thematic of memory.

First of all, societies which were an outcome of the Second World War, notably Germany with its evocations and interpretations of Nazism, and France with Vichy and the Algerian War, all convey the syndromes $^{52}$ and after-effects of the past, and prompt us into reflecting upon memory in social sciences and history. Episodes, that are difficult to hide or forget, explain the success memory has had since the $1970 \mathrm{~s}^{53}$, in the political social context following on from the Second World War, in France and elsewhere,

The fall of the Berlin Wall and the liberation of post-communist European countries (ex-Yugoslavia, Poland etc.) have given rise to their own problematic of memory which has been shaped authoritatively, because the history of these countries has been falsified and instrumentalized, especially with regard to political stakes in the Cold War, in favor of authoritarian pro-Soviet regimes ${ }^{54}$.

Finally, there are debates on history, memory and politics of pardon concerning Latin America, particularly the periods of Pinochet in Chilli, Mandela in South Africa and countries stemming from dictatorial regimes; hence the debate on peaceful memory recurs in the scientific field all over the world ${ }^{55}$.

Memory is a polysomic notion, linked both to collective or individuals' memories, but it is appropriate all the same to specify the different meanings of the notion of memory in the global scientific field.

Memory, a place to preserve a series of information, refers first of all to an ensemble of psychic functions thanks to which man can update past impressions or information, or what he represents as being past ${ }^{56}$. From this point of view, the study of memory comes from psychology, psychophysiology, neurophysiology, biology, psychiatry for troubles of the memory, the principal one being amnesia, and finally history. From here on, there is an extreme polysemy of the term memory in social sciences ${ }^{57}$. It follows therefrom, that a delimitation of the boundaries of our study has to be made immediately, especially in relation to the common sense of the understanding of memory. In the common sense, memory and souvenir are more or less similar and practically become one. These are two terms which are close to each other in everyday vocabulary for which memory is only "the faculty to preserve and be reminded of states of consciousness from the past" ${ }^{\text {,58 }}$, and there to keep the souvenir. In this essentialist vision of memory, using the term memory instead of souvenir has been widely tolerated $^{59}$. But things are different since memory has become a political stake, a historical object, which we use to instrumentalise the past. This very fluid use of the notion of memory deserves to be examined in detail ${ }^{60}$.

\footnotetext{
52 The analyses of Henry Rousso on the «Vichy Syndrome» are situated in the continuity of the "history of memory" elaborated by Pierre Nora. The latter has studied new conditions where the contemporary society establishes its relation with the past, by studying notably relations between memory and history. Cf. Henry Rousso, Le syndrome de Vichy, Paris, Seuil, 1987, p. 12.

53 Marie-Claire Lavabre, Maurice Halbwachs et la sociologie de la mémoire, Raison présente, No. 128, 1998, p. 47.

${ }^{54}$ To have an idea on the relation between memory shaped authoritarily and history, Cf. Milan Kundera, Le livre du rire et de l'oubli, Gallimard, 1978, p. 9-10.

${ }^{55}$ For a deeper study on memory and pardon, Cf. Sandrine Lefranc, Politiques du pardon, Paris, pub PUF, 2002, p. 10-50

56 Jacques Le Goff, Histoire et mémoire, Paris, Editions Gallimard, 1988, p. 105.

57 At the centre of this polemic there is the question of present and past, can we separate them on an analysis level? Jacques Le Goff, Histoire et mémoire, op.cit. p. 31-58.

${ }^{58}$ Dictionary, Le Robert, 1967, p.1067.

59 To understand the common meaning in sociology, cf. Bourdieu Pierre, Comprendre, in La misère du monde, Paris, Seuil, 1992, pp. 903-925.

${ }^{60}$ For a deeper study on the relation between memory and politics, cf. Todorov Tzventan, Les abus de la mémoire, Paris, Seuil, 1995, p.10-40.
} 


\section{A Sociological Reconstruction of the Past}

In Social frameworks of memory ${ }^{61}$, Halbwach's thesis is summed up in three proposals articulated:

- The past is not preserved, but it is reconstructed from the present.

- Memory of the past is only possible when the strategic social frameworks that individuals possess exist.

- Memory presents a further social function by which the past, mythicized, is only called on to justify social representations that are present.

According to the definition given by Maurice Halbwacks of memory as a social fact, let us go back to the three categories of attitude faced with memory that we evoked at the beginning of this research: the apolitical exile, the committed political exile, and the exile with variable geometry.

We can therefore advance the following hypothesis: Behaviour often tends to organize the stability of the psychological field at increasingly higher levels in line with the new social position.

By considering this hypothesis, we can estimate that there does exist a permanent update on memory for which there are several possible models of sociological explanations linked to lifestyles of exiles in the processes of resocialization.

This process is influenced by several factors, mainly by personal characteristics, by the length of the delay in obtaining the refugee card, by the underlying reasons for exile and, finally, to what extent, they are receptive in the host society, which largely depends on the immigration policy practiced by the society ${ }^{62}$. The memories of exiles are, as a consequence, confronted with different modes of adaptation depending on the choices they have made and which reflect the trajectory and personal journey of each of them.

We are suggesting three, within the limits of our research.

\section{Three Models of Resocialization Linked to Memory}

\section{Memory Linked to Integration}

By definition, integration is a considerably long process, in which individuals living in a foreign society, show their determination to participate in building its national identity, on economic and social terms. This new society imposes on them a series of provisions that will allow them to reach this objective. Integration presupposes the shared feeling of a certain number of fundamental values and the desire to participate in the building of a national ensemble ${ }^{63}$.

In the case of Iranian exiles, the concept of integration is related to certain basic notions representing fundamental values such as people, countries, religion, and the motivations the exiles have to go against the Iranian regime, etc. For example, what emerges from interviews with the exiles is their attachment to the country of origin, even if they have gained nationality in the host countries. This attachment in their eyes does not seem incompatible with their implication in the host country; possessing the language, having the nationality of the host country, and being determined to play the role of a citizen, all aspects which constitute in

\footnotetext{
${ }_{61}$ Maurice Halbwachs, Les cadres sociaux de la mémoire, op.cit., pp. 83-114.

${ }^{62}$ For these factors, cf, Stephen Castles, Conference on Theories of Migration and Social Change, St Anne’s College, Woodstock Road, Oxford, Tuesday 1st - Thursday 3rd July 2008.

Stephen Castles, Migration and Community Formation under Conditions of Globalization, International Migration Review, 36 (4), 1143-1168, 2002.

${ }^{63}$ Integration is a controversy notion which doesn't correspond to the precise definition of integration covering different sociological approaches. Dominique Schnapper, Qu'est-ce que l'intégration?, Paris, Gallimard, 2007, p.28-49. Also, Mohand Khellil, L'intégration des Maghrébins en France, Paris, Presses Universitaires de France, 1991, p. 52.
} 
their eyes the fundamental resources for their integration in the host society ${ }^{64}$. They try to strike a balance between the culture of the country of origin and that of the host country; memory is related to the social status acquired in this country and is no longer as pure as upon arrival.

\section{Memory Linked to Assimilation}

An immigrant is generally considered as being assimilated when he masters the language and social rituals of the host country, and can participate in social life without his difference of origin bringing him any prejudice in either economic or political daily life. Most commonly we say that, an immigrant is assimilated as soon as he has shown that he can "get along in the country". This implies, amongst other things, that in ordinary matters of life, he is capable of finding a place in the new society under the criteria of his individual skills without making reference to his racial origin or cultural heritage. But the social reality is very complex and to reach such a state of assimilation in the host country means that the migrants have to undergo many changes in lifestyle, especially in the phase of the process of professionalism in order to enter institutions ${ }^{65}$.

This very long process reminds us of the Milton Myron Gordon's well-researched and detailed schema of the process of assimilation: This schema, constitutes an operational tool for the analysis of empirical studies, and identifies seven stages in the process of assimilation the most important being: acquiring the language, renouncing religious rituals, structural assimilation, naturalization and the right to vote ${ }^{66}$.

At this stage of assimilation, certain exiles are not at all interested by memory of the past.

\section{Memory Linked to Minimum Insertion}

Different from the two previous categories of exiles, there exists another category that is made up of exiles who are not really interested in the host countries and who put their energy into preparing a revolution that is likely to change the regime and society of their country. Such revolutionary activists are usually called "outsiders", who once in exile, can rally to the revolutionary cause ${ }^{67}$.

Exiles in this category defend the fact that, despite adopting positive aspects of western culture, they don't feel in anyway an essential part of the European system in Germany, Belgium, France, or elsewhere. This category is divided into several sub-groups: the "neo-leftists", the national-religious, certain royalists, individual entrepreneurs, people who arrived at a certain age, radical activists, committed journalists ${ }^{68}$.

According to certain sociologists, such revolutionary activists are usually people obsessed by their ideology, who concentrate their lives to revolutionary causes and whose priority is to constantly think of their political activity ${ }^{69}$. In fact, this category is comprised of exiles who react politically in view of changing the government in the home country and show that they are firm in their beliefs, especially since their opposition to the political and social situation in their country is shared by some of their compatriots.

As a result, these are three models concerning the resocialization of exiles which affect their memory. It seems then that the choice of an adaptation model could constitute for memory, either a negative element, provoking the "disappearance" of this memory, either a positive element in favor of its survival. This indicates

\footnotetext{
${ }^{64}$ See life story d’ A. M, Nader Vahabi, Récits de vie des exilés iraniens, pp. 251-258.

${ }^{65}$ For an asssimilist migrants cf. Marco Martiniello, La démocratie multiculturelle, Citoyenneté, Diversité, Justice sociale, Paris, Presses de la Fondation Nationale des Sciences Politiques, 2011, pp. 68-70.

${ }^{66}$ Milton Myron Gordon, Assimilation in American Life: The Role of Race, Religion, and National Origins, New York, Oxford University press, 2009, p. 70.

67 Yossi Shain, Who is a political exile?, Internationale Migration, vol. 26, No. 4, 1988, pp. 395.

68 See life story of Ebrahim Nabavi, cf. Nader Vahabi, La quatrième socialisation de la diaspora iranienne, pp. 132-147.

69 Egon F. Kunz, The analytic framework, Exile and resettlement: refugee theory, IMR volume.15, No. 1, pp. 42-51.
} 
that the various political tendencies of Iranian exiles have their own reconstruction of memory.

Schema of the sociological variables in the host country which act on memory

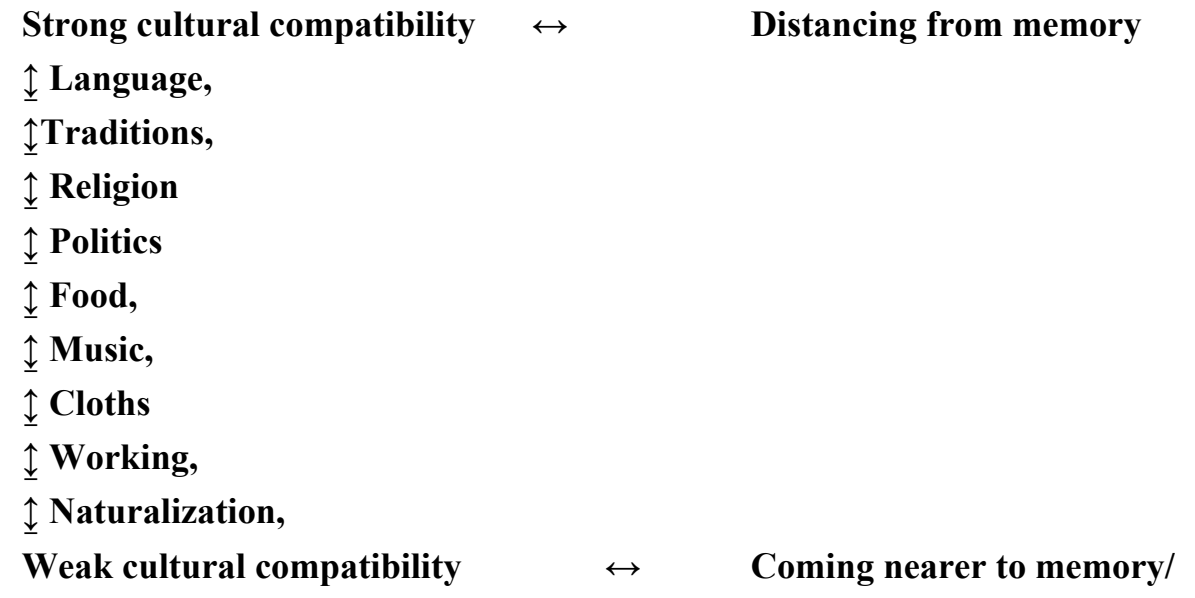

\section{Conclusion}

In the history of contemporary Iran, the Iranian revolution of 1979 is one of the events that has had the most devastating consequences and from which many lessons have been learnt. If here we are putting forward a new study on the subject, it is to advance an unprecedented problematic particularly relating to the revolution phase, intolerable for many exiles, and which had never been observed through the bitter eyes of the sacrificed utopians who the revolution "removed" from Iranian social society and found salvation in exile. To achieve this objective, this research is therefore constructed starting from the memory of political exiles seeking refuge in the countries referred to above and which represent different trends of thought.

In fact, if we "contextualize" the origin of this memory, we notice, memory that is said to be "homogeneous", exploded when democracy died in the last days of the spring revolution, following Khomeini's arrival to power. Retrospectively, few people could have imagined that this springtime would be annihilated in such a short lapse of time: "The revolution eats its children". Most exiles, who were political activists, therefore experienced the events of this significant moment (in 1981) as a trauma, because they were marked by Khomeini’s metamorphosing into a tyrant. In such a situation, exile was only the externalization of a personal "choice" imposed by the structural incertitude of a religious theocracy in the making, tolerating no other form of opposition which it saw as a basic obstacle to its ruling power.

From a point of view of methodology, we need to specify the distinctive particularity that our research discovered and which shifted the emphasis of our problematic. First of all we had envisaged carrying out a simple transcription of memories drawn from oral history, but as time went on, our research led us towards the thematic of the social dynamics of memory ${ }^{70}$. Our research was then oriented towards a sociological analysis of souvenir which suggested matching the process of commemoration with social conditions of exiles. Simultaneously, memory has then been handled as a social fact in which the determining factors were

\footnotetext{
${ }^{70}$ I was greatly inspired by the research of Marie-Claire Lavabre, Le fil rouge, sociologie de la mémoire communiste, Presses de la Fondation nationale des Sciences politiques, Paris, 1994 and «Du poids et du choix du passé. Critical reading of the «Syndrome de Vichy», in Histoire Politique et Sciences Sociales, Denis Peschanski, Michael Pollak, Henry Rousso (dir.), Paris, éd. Complexe, 1991.
} 
highlighted, contrary to what we usually understand as memory in its common meaning.

In this respect, we have relatively disseminated exiles who are also greatly affected by declining social status and social rehabilitation in the resocialization of the country the enquiry took place. In fact, the exiles interviewed, have undergone several social frameworks of memory each very different from the other; They have passed from one to the other through a mode of violent rupture and we can ask ourselves whether the social frameworks of the past, brutally snatched away from individuals, might have influenced their present life and their memory at the time they spoke about the past. We can add to that, the fact that the European context of resocialization of this memory does not reinforce greater collective identity but on the contrary the growing influence of post modernism changes original identities whilst still pushing individuals towards identities and individual memories.

By relating memory to social structures, it seems to me that there truly exists a transformation of memory that should be linked both to the habitus acquired in Iran and in particular to the trajectory and the process of resocialization of these individuals in exile.

This process is influenced by several factors, particularly by individual characteristics, political and individual conditions that reign in the country of origin, the profound reasons for exile, material and moral conditions preceding the departure from Iran, the length of time it takes to obtain the refugee card, but also, by the host society's level of receptiveness which is greatly related to how its policy of immigration is put into action. Exiles' memories are, consequently, connected to the different ways they have chosen to adapt, and they reflect the trajectory and journey of each one. Included in our sampling, we have observed three categories of behavior linked to memory according to the lifestyle of individuals.

The first category comprises individuals who adopt a style where they are "assimilated": These are exiles who are relatively uprooted, who seriously look for work and consecrate a great part of their activity to adapting in the host country.

As regards the second category, exiles from a community or associative style, they refuse to actively take part in the life of the host country, they don't look for work or master the language and only allow themselves be influenced by what is in accordance with their minds and ways of thinking. They take into account their memory, notably by commemorating past events.

As regards the third category, this mixed style between two cultures, is made up of exiles who occasionally do politics but who have difficulty in preserving their memory. In fact, the process of resocialization has distanced them and prevented them from taking a critical look at their own past which has resulted in them abandoning professional activism; The exile therefore has to try and find a balance between normal daily and political life, even if he believes that reconciling both is very difficult. In this category, we note the constant shift of memory towards new objectives and the plurality of fields of interest which serve as a support for the reorganization and reconstruction of memory.

In conclusion, although we have identified a certain number of exiles' attempts to construct a "social space", that lends itself to work on "collective memory" where individuals can put words on and share stories of their past experiences, we are constrained to underline the limited impact of these initiatives: This here is in fact only a "decibel space", certainly collective, but private.

The segmentation of exiles in relation to their political background, the complexity of a religious theocracy which has remained firm and intransient more than 36 years after the revolution, and especially, the gap between these exiles and social frameworks of the host countries which reproached them even implicitly 
for having chassed the Shah, therefore don't favor the commemoration of memory : All have the effect of confining the memorialization in some form of collective retrospection, jeopardizing the realization of a homogeneous memory within the Iranian Diaspora. To sum up, it would seem to me, that because of the diversity of social frameworks, the memory of exiles is well and truly torn apart.

\section{References}

Anselm, S. (1992). La trame de la négociation : sociologie qualitative et interactionnisme (The Web of Negotiation: Qualitative Sociology and Interactionism). textes réunis par Isabelle BAZANGER, Paris, L'Harmattan.

Arendt, H. A. (1972). Les Origines du totalitarisme. Le système totalitaire(The Origins of totalitarianism. The totalitarian system) Paris: Le Seuil.

Castles, S. (2002). Migration and community formation under conditions of globalization. International Migration Review, 36 (4), $1143-1168$.

Castles, S. (2008). Conference on Theories of Migration and Social Change. St Anne's College, Woodstock Road, Oxford, Tuesday 1st - Thursday 3rd July 2008.

Claire, L. M (1994). Le fil rouge, Sociologie de la mémoire communiste (The common theme, Sociology of communist memory). Paris: PFNS.

Claude, D. (2010). La socialisation (4th ed.) (The socialisation). Paris: Armand Colin, Paris.

Dominique, S. (2007). Qu'est-ce que l'intégration? (What is integration?). Paris: Gallimard.

Erving, G. (1961). Asylums: essays on the social situation of mental patients and other inmates. Publishing city: Anchor Books.

Farhad, K. (1993). Utopie sacrifiée (A Sacrified Utopia). Paris: Presses de la Fondation Nationale des Sciences politiques.

Fariba, A. (1998). Etre moderne en Iran(Being modern in Iran). Paris, Karthala, coll.«Recherches internationales».

http://cadmus.eui.eu/bitstream/handle/1814/22564/RSCAS_2012_29.pdf?sequence=1

http://www.fondapol.org/wp-content/uploads/2010/07/DT_Iran_Revolution_Civile_Eng.pdf

http://www.unhcr.fr/pages/4aae621e11f.html

http://www.unhcr.org/pages/4a013eb06.html

http://www.unhcr.org/statistics/populationdatabase

Iran: a civil revolution? Fondation pour l'innovation politique, October 2009

Iranian Refugees’ Alliance, New York, http://www.irainc.org/iranref/statistics.php

Jean-Louis, R. (2006). presentation of E. Hobsbawm, Franc-Tireur. Autobiography Ramsay, Paris,2005, in the Diplomatic World, February 2006.

Kunz, E. K. (1998). Les réfugiés en exode: les modèles dynamiques et les formes de déplacement. International Migration, 7(2).

Luwing, \& Luckman, T. (1967). The social construction of reality, a treatise in the sociology of knowledge. London: the Penguin Press.

Maboud, A. (1992). The making of the Iranien community in America. Clearwater: Paradis Press.

Maurice, H. (1994). Les cadres sociaux de la mémoire (Social Framework of Memory). Paris: Albin Michel.

Max, W. (1963). Le savant et le politique (The Scientist and Politics). Paris: Union générale d'éditions.

Michael, P. (2000). L'expérience concentrationnaire. Essai sur le maintien de l'identité sociale (The experience in concentration. Essay on maintaining social identitiy). Paris: Métailié

Milan, K. (1978). Le livre du rire et de l'oubli (The book of laughter and forgetting ). Publishing city: Gallimard.

Mohand, K. (1991). L'intégration des Maghrébins en Franc e (The Integration of those from Magreb in France). Paris: Presses Universitaires de France.

Myron, G. M. (2009). Assimilation in American life: The role of race, religion, and national origins. New York: Oxford University press.

Nader, V. (2008). Sociologie d'une mémoire déchirée, Le cas des exilés iraniens (Sociology of torn memory, The case study of Iranian exiles). Paris: Harmattan.

Nader, V. (2009). Récits de vie des exilés iraniens, De la rupture biographique à la nouvelle identité (Life stories of Iranian exiles, From a biographical rupture to a new identity). Paris: Elzavir.

Nader, V. (2011). La migration iranienne en Belgique, une diaspora par défaut (Iranian migration in Belgium, a diaspora by default). Paris, l’Harmattan, 2011.

Nader, V. (2012). Atlas de la diaspora iranienne (Atlas of the Iranian diaspora). Paris: Karthala. 
Pierre, B. (1992). Comprendre (to understand), in La misère du monde (The Misery of the World). Paris: Seuil.

Pierre, B. (1993). La misère du monde(The Misery of the World) Paris: éditions du Seuil.

Reza, D. M (2001). Iran: l'illusion réformiste (Iran: the reformist illusion). Paris: Presses de Sciences Po, coll. «La bibliothèque du citoyen».

Sandrine, L. (2002). Politiques du pardon (The politics of forgiveness). Paris: pub PUF.

Tzventan, T. (1995). Les abus de la mémoire (Abusing memory). Paris: Seuil.

UNCHR report 2013, http://www.unhcr.org/pages/4a013eb06.htm

UNHCR+-+Asylum+trends+2013.pdf

Yan, R. (2006). L'Iran, Naissance d'une république islamique (Iran, The Birth of an Islamic Republic). Paris: Editions de la Martinière.

Yossi, S. (1988). Who is a political exile? Revue Internationale Migration, 26(4). 